\title{
Konsep Pendidikan Jiwa Dalam Al-Qur'an
}

\author{
Najamuddin dan Mardianah \\ Dosen Fakultas Ilmu Agama Islam Universitas Islam Indragiri \\ (FIAI - UNISI) Tembilahan
}

\begin{abstract}
Al-Qur'an dalam surat Asy-Syams ayat ke delapan menyampaikan bahwa setiap jiwa manusia sudah diilhami potensi ketakwaan dan kejahatan (fujur) dengan konteks qur'ani muncul dua pendidikan jiwa yang mendasar yaitu metode ihktila' dan muhãsabah akan mengantarkan kepada pemahaman esensi kehidupan. Konsep Jiwa dalam AlQur'an adalah sebuah Solusi Qur'ani untuk Penciptaan Kesehatan Jiwa dan Implikasinya Terhadap Pendidikan Islam, merupakan tambahan pada khasanah psikologi sekaligus pendidikan Islam.
\end{abstract}

Key Words: Al Qur'an, Jiwa dan Pendidikan

\section{A. Pendahuluan}

Al Qur'an sebagai sumber utama pengembangan konsep pendidikan Islam dapat dibuktikan dengan nyata dan akurat serta dapat dikatakan lebih unggul, sebagai contoh konsep dasar untuk mengenal pendidikan jiwa pada diri manusia, meskipun dalam keilmuan Barat persoalan jiwa tidak menjadi perhatian utama, karena kebenarannya masih dianggap spekulatif dan cenderung subjektif. Ilmu psikologi modern yang menjadi referensi dalam kajian kejiwaan saat ini secara umum belum mampu mengurai secara jelas hakikat dari diri manusia. Kajiannya hanya mampu mengurai prinsip-prinsip umum dan gejala dari jiwa manusia yang teraktualisasikan melalui jasad.

Berbeda halnya dalam tradisi keilmuan Islam kajian jiwa justru mendapat perhatian penting. Hampir semua ulama, kaum sufi dan filosof muslim ikut berbicara tentangnya dan menganggapnya sebagai bagian yang lebih dahulu diketahui oleh manusia. Karena dimensi jiwa dalam Islam lebih tinggi dari sekedar dimensi fisik karena jiwa merupakan bagian metafisika. Ia sebagai penggerak dari seluruh aktivitas fisik manusia. Meskipun saling membutuhkan antara jiwa dan jasad tanpa harus dipisahkan, namun peran jiwa akan lebih banyak mempengaruhi jasad. 
Manusia telah diciptakan dengan bentuk yang sempurna dan tumbuh berkembang dengan risalah langit menghendaki perbaikan universal, dengan menjadikan jiwa manusia sebagai prioritasnya. Satu-satunya alasan mengapa risalah para Nabi tetap kekal dan sanggup mewarnai hidup orang-orang yang beriman adalah kerena "jiwa manusia" dijadikan titik sasarannya dan poros pembinaannya dengan berasaskan firman Allah SWT dalam surah Asy-Syams ayat 7-9 :

"Dan jiwa serta penyempurnaannya (ciptaannya), maka Allah mengilhamkan kepada jiwa itu (jalan) kefasikan dan ketakwaannya, sesungguhnya beruntunglah orang yang menyucikan jiwa itu".

Pendidikan Islam banyak berfokus melakukan kajian terhadap jiwa dan berbagai kondisi serta wataknya dan memperhatikan urusan hati, dengan segala perasaan dan suasananya yang bersumber dari dalam diri manusia, bukan dari luar.

\section{B. Pembahasan}

\section{a. Mengenal makna jiwa / النفس}

Kata jiwa berasal dari bahasa arab (النفس ) atau nafs' yang secara harfiah bisa diterjemahkan sebagai diri atau secara lebih sederhana bisa diterjemahkan dengan jiwa, dalam bahasa Inggris disebut soul atau spirit. Secara istilah kata jiwa dapat merujuk pada beberapa pandangan ulama dan filusuf muslim. Para filosof muslim terutama Al-Kindi, Al-Farabi dan Ibn Sina, umumnya sepakat mendefinisikan bahwa jiwa adalah "kesempurnaan awal bagi fisik yang bersifat alamiah, mekanistik dan memiliki kehidupan yang energik." Secara lebih rinci yang dimaksudkan "kesempurnaan awal bagi fisik yang bersifat alamiah adalah bahwa manusia dikatakan menjadi sempurna ketika menjadi makhluk yang bertindak. Sebab jiwa merupakan kesempurnaan pertama bagi fisik alamiah dan bukan bagi fisik material.

Kemudian makna 'mekanistik' adalah bahwa badan menjalankan fungsinya melalui perantara alat-alat, yaitu anggota tubuhnya yang bermacam-macam. Sedangkan makna 'memiliki kehidupan yang energik' adalah bahwa di dalam dirinya terkandung kesiapan hidup dan persiapan untuk menerima jiwa. ${ }^{1}$

Nampaknya definisi jiwa di atas sedikit berbeda dengan Ibn

1 Mahmud Qasim, Fi an-Nafs wa al-Aql li Falasifah al-'Ighriq wa al-Islam, cet. IV,(Kairo, Maktabah al-Injilu al-Mishriyah, 1969), 73-74. 
Hazm yang mendefinisikan jiwa bukan substansi tapi ia adalah nonfisik. Jiwa mempersepsikan semua hal, mengatur tubuh, bersifat efektif, rasional, memiliki kemampuan membedakan, memiliki kemampuan dialog dan terbebani. Jiwa adalah letak munculnya berbagai perasaan, kesedihan, kebahagiaan, kemarahan, dan sebagainya. Lebih jauh Ikhwan Ash-Shafa mendefinisikan jiwa sebagai substansi ruhaniah yang mengandung unsur langit dan nuraniyah, hidup dengan zatnya, mengetahui dengan daya, efektif secara tabiat, mengalami proses belajar, aktif di dalam tubuh, memanfaatkan tubuh serta memahami bentuk segala sesuatu. ${ }^{2}$

Merujuk pada pendapat kalangan sufi, akan terlihat definisi yang sangat kontras dari apa yang dipahami oleh para filosof muslim. Hampir seluruh sufi sepakat bahwa jiwa adalah sumber segala keburukan dan dosa. Sebab ia adalah sumber syahwat dan keinginan meraih kesenangan. Al-Qusyairi mempertegas bahwa jiwa itu berwujud sendiri. Ia merupakan unsur halus yang dititipkan dalam raga manusia. Unsur halus ini merupakan tempat akhlak yang sakit. ${ }^{3}$ Jika diperhatikan dari penjelasan tersebut barangkali jiwa yang dimaksudkan kaum sufi lebih mengarah pada istilah hawa nafsu. Jika jiwa dalam makna itu yang dimaksudkan, maka jelas berbeda dengan pandangan filosof muslim yang menganggap jiwa adalah ruh yang berupa zat dan substansi.

Nafs dikalangan para filsuf Islam, seperti Al-Kindi menjelaskan bahwa pada jiwa manusia terdapat tiga daya, yaitu :

1. Daya nafsu ( القوة الثُهوبة daya ini berada di dalam perut

2. Daya berani (القوة الغضبية ) bertempat di dalam dada

3. Daya pikir ( القوة الناطقة yang berpusat di kepala

Menurut al-Ghazali nafsu diartikan "Perpaduan kekuatan marah (ghadlab) dan syahwat dalam diri manusia”. Kekuatan ghadlab pada awalnya tentu untuk sesuatu yang positif seperti untuk mempertahankan diri, mempertahankan agama dan sebagainya. Dengan adanya ghadlab itulah jihad diperintahkan dan kehormatan diri terjaga.

2 Muhammad Ustman Najjati, Ad-Dirasat al-Nafsaniyah 'inda al-Ulama al-Muslimin, (Kairo, Darul Asy-Syuruq, 1993), h. 98.

3 Amin an-Najar, Tasawwuf an-Nafsi, (Kairo, al-Hay-ah al-Mishriyah, 2002), h. 22. 
Mendefinisikan jiwa bukanlah perkara yang mudah bahkan lebih sukar daripada membuktikan adanya. Maka, wajar ketika ditemukan ada perbedaan dalam memahami arti dari jiwa, karena perbedaan tersebut sebenarnya hanya karena metode dan cara pandang yang berbeda antara para filosof dan kalangan Sufi. Metode analisis filosof lebih mengedepankan pada akal dan logika, sedangkan sufi lebih mengedepankan pada intuisi, sehingga menimbulkan kesimpulan berbeda. Terpenting di sini adalah bahwa definisi jiwa mengacu pada substansi utama yang ada pada diri manusia, yang memiliki peran sentral mengatur gerak dari tubuh dan memiliki daya dan cara kerjanya sendiri. Tentu akan jauh lebih luas dari sekedar definisi jika melihat bagaimana Al-Qur'an dan Hadis menjelaskan tentang keberadaan jiwa.

\section{b. Mengenal Makna Jiwa dalam Konteks Al-Qur'an}

Al-Qur'an memberikan apresiasi yang sangat besar bagi kajian jiwa (nafs) manusia. Hal ini bisa dilihat ada sekitar 279 kali AlQur'an menyebutkan kata jiwa (nafs). Dalam Al-Qur'an kata jiwa mengandung makna yang beragam (lafzh al-Musytaraq). Terkadang lafaz nafs bermakna manusia (insan).

"Takutlah kalian kepada hari di mana seorang manusia (nafs) tidak bisa membela manusia (nafs) yang lainnya sedikitpun." ${ }^{4}$

"Sesungguhnya orang yang membunuh seorang manusia (nafs) bukan karena membunuh (nafs) manusia yang lainnya, atau melakukan kerusakan di muka bumi, seolah-olah dia membunuh seluruh manusia." ${ }^{5}$

Kata nafs juga menunjukkan makna Zat Tuhan, "Aku pilih engkau untuk Zat (nafs)-Ku." Juga bermakna hakikat jiwa manusia yang terdiri dari tubuh dan ruh, "Dan kalau Kami menghendaki, niscaya Kami akan berikan kepada tiap-tiap jiwa petunjuk." Dan "Allah tidak membebani (jiwa) seseorang melainkan sesuai dengan kesanggupannya." Selain itu ditujukan maknanya kepada diri manusia yang memiliki

4 QS. Al-Baqarah[2]: 48.

5 QS. Al-Maidah[5]: 32.

6 QS. Thaha[20]: 41.

7 QS. As-Sajadah[11]: 13.

8 QS. Al-Baqarah: 286. 
kecenderungan, "Maka, hawa nafsu Qabil menjadikannya menganggap mudah membunuh saudaranya, sebab itu dibunuhnyalah, maka jadilah ia seorang di antara orang yang merugi." Lafaz nafs yang bermakna bahan (mahiyah) manusia. ${ }^{10}$ Kehendak (thawiyah) dan sanubari (dhamir) ${ }^{11}$, dan beberapa makna lain yang secara umum dijelaskan dalam alQur'an yang tidak mungkin dijelaskan satu persatu. ${ }^{12}$

\section{c. Mengenal Potensi Jiwa (Jasmaniah dan Rohaniyah)}

Manusia sebagai suatu sistem terdiri dari beberapa komponen sistem yang memiliki fungsi-fungsi tertentu yang antara satu dengan yang lainnya saling mempengaruhi dalam satu integritas yang kuat. Di sini manusia dipandang terdiri atas dua unsur kemanusiaan yaitu komponen psikologis dan fisiologis atau komponen rohani dan jasmani.

\section{Potensi Jasmaniah}

Manusia mempunyai dua potensi penunjang kekhalifahan, yakni potensi jasmaniah dan potensi ruhaniah. Dua potensi ini berkaitan dengan tugas-tugas dalam mengelola bumi dan memakmurkannya atau disebut sebagai tugas-tugas kekhalifahan. hal ini menjadi realitas historis sebagaimana disinggung dalam Al-Qur'an berkaitan dengan pesan kekhalifahan oleh Nabi Saleh kepada kaumnya, yakni kaum tsamud. ${ }^{13}$

9 QS. Al-Maidah: 30.

10 Lihat QS. Al-Qiyamah[75]: 2, Yusuf[12]: 53, Al-Fajr[89]: 27-28 dan AnNazi'at[79]: 40.

11 Lihat, QS. Ar-Ra'd[13]: 11 dan Qaf[50]: 16.

12 Muhammad Izzuddin Taufiq, Panduan Lengkap dan Praktis Psikologi Islam, (Jakarta, Gema Insani Press, 2006), h. 74.

13 Dijelaskan dalam QS Hud (11:61) mengandung unsur seruan pertama, berkenaan dengan seruan untuk menyembah Allah, menurut ulama fiqih melahirkan konsep Abdullah dalam bentuk penyembahan (Ubudiah); kedua, seruan untuk mengesakan Allah karena tidak ada Tuhan selain Allah (Uluhiah); tiga, berupa peringatan atas proses kejadian dan fungsinya sebagai pemakmur bumi sekaligus pembangunnya. Mencakup hubungan dengan Allah (hablun min Allah) maupun hubungan dengan sesama manusia (hablun min an-nas); dan keempat berkenaan dengan seruan untuk ampunan dan bertobat kepada Allah, yang akhirnya melahirkan konsep etika (akhlak). 


\section{$10 \frac{\text { Jurnal AL-AFKAR }}{\text { Vol. II, No. II, Oktober } 2013}$}

Penjelasan mengenai potensi jasmaniah ini, secara tersirat Al-Qur'an menunjukkan fakta historis bahwa pengganti-pengganti sesudah lenyapnya kaum Nuh, yaitu 'Aad seperti diceritakan memiliki kelebihan kekuatan tubuh dan perawakan yang tinggi hingga mencapai kira-kira $6000 \mathrm{~m} .{ }^{14}$

Allah menciptakan manusia dari keadaan yang sangat lemah ketika masih bayi. Secara bertahap, dari waktu ke waktu mengalami pertumbuhan dan perkembangan dengan segala kompleksitasnya dia menjadi kuat perkasa sehingga manusia mampu merealisasikan segala aktivitas hidupnya, baik berupa interaksi dengan Tuhan, alam sekitarnya dan lingkungan, termasuk dengan manusia. Baru setelah faktor usia mulai bertambah, keadaan jasad dan kekuatannya mulai mengendur, stamina tubuh semakin berkurang, pada saatnya dia akan kembali seperti keadaannya sediakala, yakni lemah, rapuh dan lain sebagainya. ${ }^{15}$

Dalam rangka mewujudkan interaksi kemanusiaan ini, jasad atau tubuh manusia dilengkapi oleh Allah dengan beberapa alat yang disebut dengan panca indera antara lain sebagai berikut.

\section{a. Mata ('Ainun / عين)}

Dalam Al-Qur'an makna kata 'ainun diklasifikasikan menjadi dua bagian, pertama, kata ini digunakan secara denotative atau dalam arti yang sebenarnya yakni mata kepala untuk melihat suatu peristiwa atau gejala yang terjadi di lingkungan sekitar. ${ }^{16}$ Makna kedua dipergunakan secara konotatif atau makna kiasan atau makna majazi. Dalam makna ini kata 'ainun berarti 'sumber mata air' dan sebagai kiasan mata. ${ }^{17}$

\section{b. Telinga (Udzunun / أذن )}

Telinga sebagai alat untuk mendengarkan atau alat untuk menangkap informasi. Al-Qur'an menekankan kepentingan pendengaran, namun bahasa yang dipergunakan tidak ada kata udzunun,

14 Ahmad As-Shawi, Hasiyah Al-Alama As Shawi 'Ala Tafsiri Al-Jalalain.

15 Tercermin dalam QS Ar-Rum (30:54).

16 QS Ali - Imran (3:13)

17 QS Al-Baqarah (2:60) 
tetapi sami'a yang merupakan kehendak abstrak. ${ }^{18}$

c. Hidung (Anfun / أنف )

Alat indera ini berfungsi untuk mencium aroma wangi atau sebaliknya. Ayat sangat jarang menggunakan kata ini dan pembicaraan fungsinya. Satu-satunya ayat yang menampilkan penjelasan indera berkaitan dengan kasus hukuman yang mengisyaratkan adanya keseimbangan dalam menetapkan hukuman. ${ }^{19}$

\section{d. Mulut (Fam / فم )}

Mulut adalah indera yang berfungsi untuk berbicara dan menyampaikan informasi. Karena kemampuan ini, manusia disebut dengan hayawanun nathiq (hewan yang mampu berbicara). Keseluruhan kata afwah/fam melukiskan pembicaraan yang tidak berdasarkan fakta yang sebenarnya atau perkataan yang berbeda dengan apa yang sebenarnya ada dalam hatinya. ${ }^{20}$

e. Kulit (Jildun/ جلد )

Lafadz julud dalam Al-Qur'an dipergunakan juga untuk menyebut kulit hewan. Kulit manusia dan kulit hewan tidaklah jauh berbeda, sama-sama sebagai pembalut dan pelindung dari sengatan sinar matahari atau lainnya, begitu juga dengan sifat-sifatnya yang sering gemetar dan menggigil. Hanya saja penyebabnya mungkin sedikit berlainan dan tidak pernah terjadi pada hewan. ${ }^{21}$

\section{Potensi Ruhaniah}

Potensi ruhaniah manusia sebagaimana di ketahui dasar manusia itu terdiri dari dualisme yang saling melengkapi, yaitu manusia terdiri dari badan kasar (jasmani) dan badan halus (rohani), kalau jasmani digerakkan oleh fikiran, perasaan dan kemauan yang melahirkan kekuatan lahir. Sedangkan rohani digerakkan oleh cipta, rasa, dan karsa yang melahirkan kekutan batin.

Istilah "ruhaniah" adalah sebutan bagi keseluruhan yang ada

18 QS Ali Imran (3:179), QS Al-Isra' (17:36), QS Al-Zumar (39:18)

19 QS. Al-Maidah (5:45)

20 QS Ali-Imran (3:167)

21 QS Al-Zumar (39:23) 


\section{$12 \frac{\text { Jurnal AL-AFKAR }}{\text { Vol. II, No. II, Oktober } 2013}$}

pada bagian immateri. Unsur abstrak yang tidak dapat ditangkap oleh panca indera. Aspek inilah yang menjadikan manusia sebagai makhluk tertinggi diantara makhluk-Nya. Menurut para sufiah, manusia adalah makhluk yang paling sempurna dimuka bumi ini. Bukan saja karena dia merupakan mazhaz (penampakan atau tempat kenyataan) asma' dan sifat Allah yang paling lengkap dan menyeluruh. ${ }^{22}$

Pemahaman ini mengantarkan mereka pada kesimpulan bahwa jasad hanyalah sekedar alat atau kendaraan bagi ruhani dalam melakukan aktivitasnya. Manusia pada hakikatnya bukanlah jasad lahir yang berada dalam dirinya yang selalu mempergunakan tugasnya. Perangkat-perangkat ruhani yang bersifat immateri itu, menurut Musa Asy'ari mengutip statemen Fazlul Rahman, ${ }^{23}$ adalah sebagai berikut.(الروح , والعقل , والقلب ,والنفس )

\section{a. Ruh (al-Ruh/الروح)}

Al-Qalb dalam pengertian pertama adalah al-qalb al-jasmani atau al-lahm al-shanubari, yaitu daging khusus yang berbentuk seperti jantung pisang yang terletak di dalam dada sebelah kiri. Al-Qalb dalam pengertian pertama ini erat kaitannya dengan ilmu kedokteran dan tidak banyak menyangkut maksud-maksud agama serta kemanusiaan. Al-Qalb tersebut juga terdapat pada hewan. Al-Qalb dalam pengertian kedua menyangkut jiwa yang bersifat lathif, roh】niah, dan robb\ni, dan mempunyai hubungan dengan al-qalbal-jasmani. Al-Qalb dalam pengertian kedua inilah yang merupakan hakekat dari manusia, karena sifat dan keadaannya yang bisa menerima, berkemauan, berfikir, mengenal, dan beramal. Selanjutnya kepadanyalah ditujukan perintah dan larangan, serta pahala dan siksaan Allah.

Kata al-Ruh terulang sebanyak 21 kali yang tergelar dalam 19 surat dan dipakai dalam berbagai arti dan konteks. Pertama kata alRuh dikaitkan dengan kata Quds atau Malaikat Jibril, salah satunya

22 Berkat jasad dan perlengkapannya ini, manusia ditunjuk sebagai khalifah. Maka, wajarlah bila jamaah malaikat mengadakan protes atas ketetapan Allah. Menurut para mufassir, protes tersebut tidak dimaksudkan sebagai penolakan tetapi untuk mengetahui apa sebenarnya rahasia dan hikmah dibalik pengangkatan khalifah tersebut. Penjelasan dalam tafsir Ibnu Ktasir.

23 Asy'ari, Musa, Manusia pembentuk kebudayaan dalam Al-Qur'an, (Jakarta : LSFI, 1992) hlm. 62. 
karena dapat menghidupkan agama sebagaimana badan dapat hidup disebabkan adanya ruh. Kedua, "Ru】han min amrinã" dikatakan demikian karena ia menyebabkan hidupnya agama dan kemaslahatan di dunia. Ketiga, ruh yang dapat menghidupkan orang mati. Keempat, adalah ruh Tuhan yang dianugerahkan pada Nabi Isa as, sebagai penghormatan kepadanya. ${ }^{24}$

Dalam tafsir Ibnu Katsir ${ }^{25}$ kata kunci untuk memahami ruh dalam konteks Al-Qur'an terletak pada kata Amr yang mempunyai arti dalam berbagai makna berikut. Pertama, diartikan sebagai 'perkara' atau 'unsur' kedua diartikan sebagai 'perintah'. Ketiga, diartikan sebagai 'hukum' atau 'aturan Tuhan pada ciptaannya'. Keempat diartikan sebagai 'alam'. ${ }^{26}$

Kata ruh dalam Al-Qur'an diberi penjelasan sebagai 'amrun minallah' mempunyai pengetahuan pimpinan perintah, perkara, dan urusan dari Allah. Sebagai layaknya pemimpin, maka akan senantiasa memberi arahan bagi setiap manusia. Dalam pengertian sebagai pemimpin dan pemberi petunjuk itulah, maka dalam Al-Qur'an ruh juga dipakai untuk menyebut nama malaikat dengan sebutan 'al-ruh al-amiØn', yakni malaikat Jibril yang dipercaya untuk menyampaikan wahyu Allah kepada para Nabi dan Rasul-Nya sekaligus sebagai pembimbingnya. Begitu pula dengan sebutan 'ruh al-quds' yang senantiasa mengajak kearah kesucian dan kemurnian aktivitas.

\section{b. Akal (al-Aql / العقل)}

Berasal dari bahasa Arab 'al-aql' dalam bentuk kata benda (ism, noun) bentuk kata kerjanya adalah 'aqala' yang berarti 'mengikat' dan 'menahan'. Akal dipahami sebagai daya berpikir yang berpusat di

24 QS Al-Baqarah (2:87); QS Al-Syu'ara (26:193); QS Al-Nahl (16:2); QS Al-Sajdah (32:9)

25 Ibnu Katsir dalam tafsir Al Qur'an Al Adzim, Asia: Ayirkah An Nur 1336 bahwa pengungkapan kata al Ruh dalam Al Qur'an selalu diberi keterangan sebagai amr dari Tuhan, bahkan ketika Nabi Muhammad Saw ditanya oleh beberapa orang yahudi mengenai ruh, sejenak nabi terdiam yang menurut dugaan Ibnu Mas'ud, ketika ayat yang menegaskan bahwa masalah ruh adalah amr dari Tuhan.

26 Penegasan kata amr dalam QS Al-Isra (17: 85) ; QS Ali Imran (3: 159) ; QS Al Thalaq (65: 5) ; QS Al A'raf (7: 54); QS Al Qomar (54: 12). 
kepala, juga dikatakan sama dengan al-Qalb yang berpusat di dada.

Penggunaan akal berkaitan dengan delapan hal. Pertama, keimanan; kedua, untuk memahami alam semesta; ketiga, memahami proses dinamika kehidupan manusia; keempat, untuk memahami tanda-tanda kebesaran Tuhan (ãyatullah); kelima, untuk memahami kitab suci; keenam, kehidupan akhirat; ketujuh, dengan hukum moral; dan kedelapan dengan shalat. ${ }^{27}$

Akal dalam perspektif Al-Qur'an tidak hanya dipergunakan untuk realitas konkret, seperti proses dinamika alam semesta dan kehidupan manusia. Akan tetapi, akal perspektif juga digunakan untuk memahami realitas yang berdimensi ghaybiyah, seperti kehidupan akhirat, nilai-nilai moral untuk memahami ayat-ayat Allah, baik ayat qauliyah maupun kauniyah.

Menggunakan akal berarti menggunakan kemampuan memahami, baik kaitannya dengan realitas yang konkret oleh pikiran. Sedangkan, realitas abstrak dipahami oleh kalbu karena pikiran dan kalbu merupakan instrument akal sebagai daya ruhani untuk memahami kebenaran. Pemahaman ini dengan jelas dapat dilihat pada keterangan QS Ali Imran (3 : 190-191) berikut.

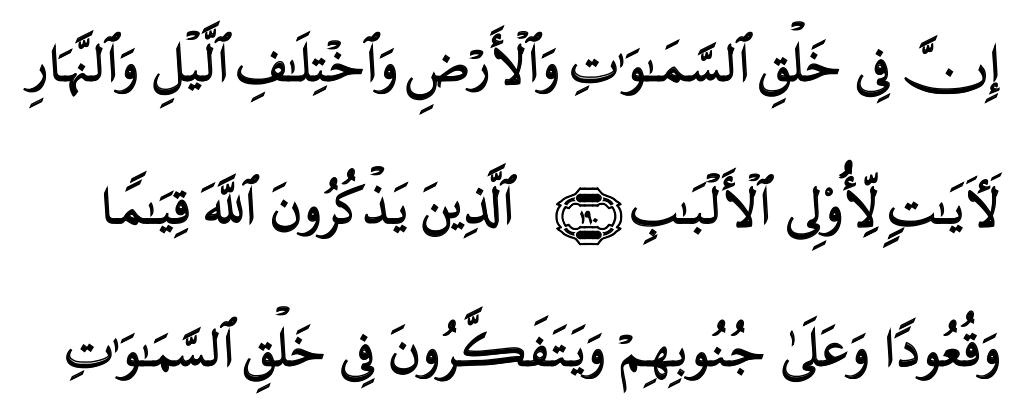

27 Dalam Al-Qur'an terdapat 49 ayat yang menjelaskan tentang penggunaan akal, yaitu dengan kata 'aqala terdapat dalam 1 ayat dan Ta'qiwn dalam 24 ayat, na'qiwm, ya'qilun masing-masing dalam 1 ayat dan ya'kilu dalam 22 ayat kaitannya dengan aspek-aspek di atas dapat dilihat di QS Al Baqarah (2;76), QS Al Baqarah (2: 164), QS Al Hajj (22: 46), QS Al Baqarah (2: 73), QS Yusuf (12: 2), QS Al Mulk (67: 10), QS Al An'am (6: 151) dan QS Al Maidah (5:58). 


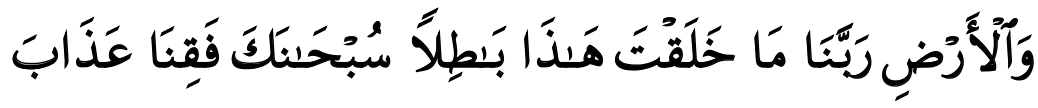

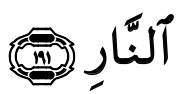

"Sesungguhnya, dalam penciptaan langit dan bumi, dan silih bergantinya malam dan siang terdapat tanda-tanda bagi orang-orang yang berakal, (yaitu) orang-orang yang mengingat Allah sambil berdiri atau duduk atau dalam keadaan berbaring dan mereka memikirkan tentang penciptaan langit dan bumi (seraya berkata) "Ya Tuhan kami, tiadalah Engkau menciptakan ini dengan sia-sia, Mahasuci Engkau, maka peliharalah kami dari siksa neraka”.

Ayat ini mengandung pengertian bahwa memikirkan proses penciptaan alam adalah kegiatan berpikir yang berpusat di otak (kepala). Sedangkan, mengingat Tuhan (dzikrullah) merupakan kegiatan berpikir yang berpusat di kalbu yang ada di dalam. Dengan demikian, kegiatan akal adalah merupakan kesatuan antara pemikiran dan kalbu dalam rangka memahami kebenaran.

Hal yang perlu di ingat adalah bahwa kata al'aql (sebagai kata dasar) tidak di jumpai di dalam Al-Qur'an Al- Karim sama sekali, melainkan kata devirasi atau bentuk jadian yang berupa kata kerjanya, semisal ya'qilu, na'qilu, ta'qiluna, ya'qiluna, 'aqillu yang mencapai 50 kata. $^{28}$

\section{c. Al-Qalb / القلب}

Al-Qalb biasa diterjemahkan dengan hati. Sebenarnya terjemahan yang tepat dari kata qalb adalah 'jantung'. Akan tetapi, dalam pembahasan ini akan dipakai kata hati sebagaimana yang sudah biasa. Dalam bahasa Arab, kata hati disebut juga dengan al-kabid (الكبد ).

Hati sifatnya seperti diisyaratkan oleh kata padanannya kalbu. Kalbu berasal dari bahasa Arab yang berakar dari kata kerja qalaba yang artinya 'membalik'. Maksudnya, hati berpotensi untuk berbolak balik, disuatu saat marah dan senang, di saat lain merasa susah, suatu kali mau menerima atau menolak. ${ }^{29}$ Sedangkan, bentuk jamak

28 Muhammad 'Abdullah asy-Syarqawi, Sufisme dan Akal, (Bandung: Pustaka Hidayah, 2003), hlm 73.

29 M. Quraish Shihab, Lentera Ilahi (Bandung: Mizan, 1994), hlm. 7-8. 
dari kata qalb adalah kata quluub yang berarti hati.

Al-Qalb mempunyai dua pengertian. Pertama, adalah segumpal daging yang berbentuk bulat panjang dan terletak di dada sebelah kiri, yaitu segumpal daging yang mempunyai tugas tertentu. Didalamnya ada rongga-rongga yang mengandung darah hitam sebagai sumber ruh. Sedangkan arti kedua mengandung arti halus yang bersifat ketuhanan dan ruhaniah. Inilah hakikat manusia yang menjadi sasaran dari segala perintah dan larangan Tuhan. Ia akan disiksa, dicela, dan dituntut segala amal perbuatannya. Dalam Al-Quran terdapat kurang lebih 101 ayat yang menjelaskan kata benda qalb ataupun bentuk jamaknya,yaitu al-Quluub.

\section{d. Awal Pengaktifan Jiwa Manusia}

Ilmu Psikologi mempersoalkan tingkah laku manusia, baik yang teramati maupun tidak teramati. Secara umum aktivitas-aktivitas manusia itu dapat dicari hukum psikologis yang mendasarinya. Para pendidik perlu memahami kekuatan-kekuatan jiwa manusia, maka mereka pun perlu mengetahui hukum-hukum psikologis yang mendasari setiap aktivitas manusia yang dalam hal ini yaitu anak didik.

Al-Qur'an adalah kalam yang diturunkan oleh Allah kepada 'jiwa' Nabi yang paling sempurna, yaitu Rasulullah SAW, Al-Qur'an menyebut nafsu (jiwa) dalam bentuk-bentuk kata jadian ( أنفس نفوس نفس متتافس يتتافس تتفس (). Pada awal masa turunnya Al-Qur'an kata nafsu digunakan untuk menyebut jiwa atau sisi dalammanusia, sementara ruh digunakan untuk menyebut malaikat Jibril atau anugerah ketuhanan yang istimewa.

Sastra Arab kuno ${ }^{30}$ menggunakan kata nafsu untuk menyebut diri atau seseorang. Baru pada periode sesudah Al-Qur'an secara keseluruhan masyarakat di dunia Islam menyebut jiwa dan ruh secara silang dan keduanya digunakan untuk menyebut ruhani, malaikat dan jin.

Kata nafsu yang digunakan dalam Al-Qur'an untuk menyebut manusia secara totalitas, baik manusia dengan makhluk yang hidup di dunia maupun manusia yang hidup dialam akhirat, sebelum ter-

30 Achmad Mubarak, Jiwa dalam Al-Qur'an: Solusi Keruhanian Manusia Modern (Jakarta: Paramadina, 2000), hlm. 43. 
jadi aktivitas, jiwa, secara biologis, mengalami proses pertumbuhan. Pertumbuhan manusia dari sebuah sel tunggal kemudian mengalami perubahan struktural dan fisiologis (kejasmanian). Awal konsepsi disebut dalam QS Al-Mu'minun (23: 12-14) berikut.

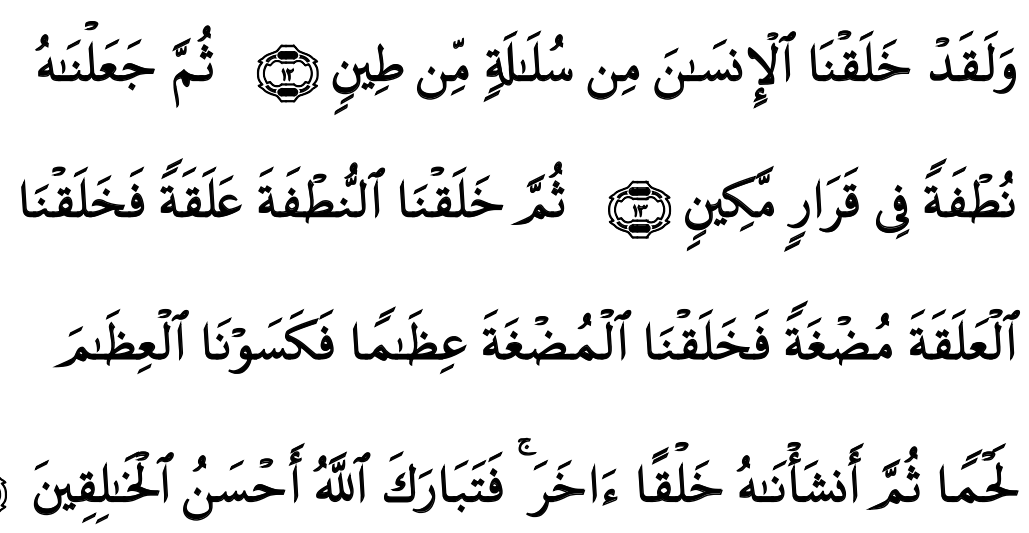

Dan sesungguhnya kami telah menciptakan manusia dari suatu sari pati (berasal) dari tanah. Kamudian kami jadikan sari pati itu air mani (yang disimpan) dalam tempat yang kokoh (Rahim). Kemudian air mani itu Kami jadikan segumpal darah, lalu segumpal darah itu Kami jadikan segumpal daging dan segumpal daging itu Kami jadikan tulang belulang, lalu tulang belulang itu Kami bungkus dengan daging. Kemudian Kami jadikan dia makhluk yang (berbentuk) lain, maka Mahasuci Allah, Pnecipta yang paling baik.

Sejak pertama kali dilahirkan oleh ibunya, Allah Swt sudah mengaktifkan jiwa manusia. Penjelasan riwayat kalimat dikeluarkan dari tulang "sulbi" itu menunjukkan saat pertama kali terjadinya konsepsi, yaitu pembuahan sel telur oleh sperma ketika sel telur dan sperma dilepaskan dari sumbernya, yakni indung telur dan testisnya yang kemudian dipertemukan dan ditempatkan di dalam Rahim. Saat itulah jiwa manusia sudah mulai terbentuk, dengan kualitas yang paling rendah dan sangat dasar, tetapi fitrahnya telah bertauhid kepada Allah Sang Pencipta Penjelasan ini tercermin dalam QS Al-A'raf (7 : 172).

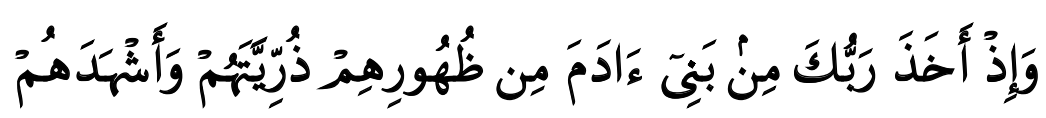




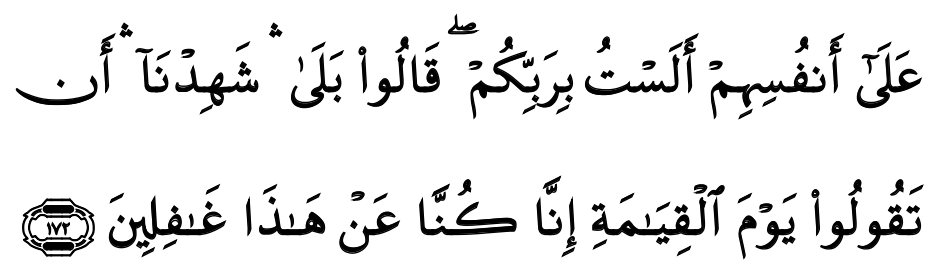

Dan (ingatlah) ketika Tuhanmu mengeluarkan keturunan anak-anak Adam dari sulbi mereka dan Allah mengambil kesaksian terhadap jiwa mereka (seraya berfirman), "Bukankah Aku Ini Tuhanmu?"Mereka menjawab, "Betul (Engkau Tuhan Kami), kami menjadi saksi". Kami lakukan yang demikian itu agar dihari kiamat kamu tidak mengatakan, "Sesungguhnya Kami (Bani Adam) adalah orang-orang yang lengah terhadap ini (keesaan Tuhan).

Ayat di atas mengisyaratkan tentang kesaksian sesuai dengan fitrah manusia. Hal ini diperkuat oleh mufassir modern, Yusuf Ali mengatakan bahwa ikatan perjanjian seorang manusia dengan Tuhannya sedemikian lengkap sejak dalam kandungan, bahwa mereka telah mengakui Allah sebagai Pencipta Alam Semesta sehingga manusia berkewajiban menyembah-Nya. Jika kita memberikan kesaksian (mengenai ketaatan kita kepada Tuhan), maka kesaksian itu dengan sendirinya menjadi tanggung jawab kita sebab ini terbawa oleh kodrat kita yang masih bersih dan belum ternoda, kodrat itulah merupakan fitrah manusia.

Al-Qur'an menegaskan bahwa "nafsu" diciptakan Tuhan dalam keadaan sempurna, sebagai perangkat dalam (ruhani) manusia, "nafsu" dicipta secara lengkap, diilhamkan kepadanya kebaikan dan keburukan agar ia dapat mengetahuinya.31

Jiwa mempunyai substansi dan esensi serta daya tersendiri. Ibnu Maskawaih menjelaskan bahwa akal hanyalah daya-daya jiwa dan merupakan manifestasi dari adanya jiwa. Jiwa mempunyai tiga cabang/tiga kekuatan, yaitu :

1. Kekuatan untuk berpikir memahami dan membedakan sesuatu (An-Nafsun Nathiqah)

2. Kekuatan marah, berlaku berani rindu kepada kekuasaan dan sebagainya (An-Nafsus Sab'iyah)

3. Kekuatan yang menimbulkan syahwat, makan, minum, dan

31 Op. Cit., Ahmad, Mubarok, hlm. 54 
kelezatan-kelezatan fisik lainnya.

Antara kekuatan-kekuatan jiwa itu, saling berlomba maju dan hendak menjadi dirinya paling depan sehingga sering yang satu mendapat tekanan dari yang lain. Jiwa itu adalah kekal, ia tidak hancur dengan hancurnya jasad. Jiwa itu pulalah yang akan menerima balasan diakhirat kelak, kebahagiaan jasmani bersifat sementara, tetapi kebahagiaan ruhani yang dirasakan jiwa adalah kekal. ${ }^{32}$

Jiwa yang diilhamkan kepada kebaikan akan memberi pedoman hidup manusia dalam beragama melalui tingkah laku. Fungsi dan peran agama akan memberi pengaruh terhadap individu, baik dalam bentuk sistem nilai, motivasi, maupun membentuk kata hati (conscience).

Kerinduan pada agama memang kerinduan fitri. Hal ini diakui secara tegas oleh Islam."Tidak ada seorang bayi dilahirkan, kecuali dengan membawa fitrah (agama)."Fitrah adalah konsep utama psikologi islami berarti kejadian atau penciptaan. Fitrah adalah sesuatu yang telah menjadi bawaannya sejak lahir atau keadaan mula-mula. Dijelaskan dalam QS Al-Rum (30:3)

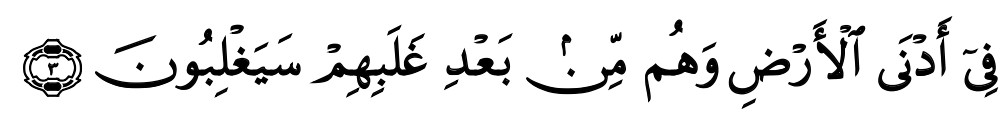

Di negeri yang terletak dan mereka sesudah dikalahkan itu akan menang.

Meskipun perbedaan pendapat yang menyangkut kebutuhan jiwa akan tubuh, Ibn 'Arabi dan Mulla Shadra dalam dua paparan yang berbeda, mendukung keyakinan yang sama. Ibn 'Arabi memandang tubuh sebagai padang pertumbuhan bagi jiwa, sementara Mulla Shadra melihat tubuh sebagai kendaraan jiwa, kedua citra itu menyampaikan makna jiwa yang menggunakan tubuh untuk perbuatan-perbuatannya sendiri.

32 Baharuddin, Pendidikan $\mathcal{E}$ Psikologi Perkembangan (Jakarta, Ar Ruzz Media, 2010), hlm. 28. 


\section{F. Kesimpulan}

Secara operasional konsep pendidikan jiwa dalam al-Qur'an, adalah sebagai realisasi dari kesanggupan mengoptimalkan potensi dan urgensi qalb dan 'aql dalam mengendalikan diri (nafs) kejiwaan manusia. Implikasinya dalam pendidikan Islam baik input maupun output dapat terjamin kualitas dan kuantitasnya.

Sesungguhnya Islam memiliki sebuah konsep yang utuh mengenai jiwa. Setiap para ulama memiliki sebuah pandangan yang mengakar kuat pada tradisi Islam. Meskipun kita melihat kecenderungan para Filosof muslim mengutip banyak pemahaman jiwa dari para $\mathrm{Fi}$ losof Yunani seperti Aristoteles, Plato, Galien, Platonis dan lainnya. Namun sejatinya konsep yang dikembangkan berdasarkan cara pandang seorang muslim sehingga apa yang dikemukakan tidak keluar dari worldview Islam. Pemahaman yang beragam dalam memahami eksistensi jiwa ini juga dalam rangka memahami kebenaran Mutlak yaitu Sang Pencipta. Maka ketika seseorang memahami dirinyayaitu jiwa beserta seluruh yang ada pada diri manusia, maka ia akan mengenal TuhanNya. Seperti kata Ali bin Abi Thalib, man 'arafa nafsahu faqad 'arafa rabbahu (barang siapa mengenal dirinya (jiwa), maka ia akan mengenal Tuhannya.

Pandangan positif mempercayai bahwa manusia diciptakan dalam keadaan positif pada kebaikan, namun faktor eksternal dapat mengubah hal positif itu. Pandangan ini adalah khas psikologi islami yang menepatkan Al-Qur'an pada kedudukan yang paling tinggi dalam merumuskan konsep-konsep psikologi islami.

Secara operasional konsep pendidikan jiwa dalam al-Qur'an, adalah sebagai realisasi dari kesanggupan mengoptimalkan potensi dan urgensi qalb dan 'aql dalam mengendalikan diri (nafs) kejiwaan manusia. Implikasinya dalam pendidikan Islam baik input maupun output dapat terjamin kualitas dan kuantitasnya. 


\section{Daftar Pustaka}

Achmad Mubarak, Jiwa dalam Al Qur'an: Solusi Keruhanian Manusia Modern, Jakarta: Paramadina, 2000.

Ahmad As-Shawi, Hasiyah Al-'Alama As Shawi 'Ala Tafsiri Al-Jalalain. Al Qur'an dan Hadits

Amin an-Najar, Tasawwuf an-Nafsi, Kairo, al-Hay-ah al-Mishriyah, 2002.

Asy'ari, Musa, Manusia pembentuk kebudayaan dalam Al-Qur'an, Jakarta : LSFI, 1992.

Baharuddin dan Dholifah, Metafisika dan Perannya Bagi Pendidikan, 2007

Baharuddin, Pendidikan $\mathcal{F}$ Psikologi Perkembangan, Jakarta, Ar Ruzz Media, 2010.

M. Quraish Shihab, Lentara Ilahi, Bandung: Mizan, 1994.

Mahmud Qasim, Fi an-Nafs wa al-Aql li Falasifah al-'Ighriq wa al-Islam, cet. IV, Kairo, Maktabah al-Injilu al-Mishriyah, 1969

Muhammad 'Abdullah asy-Syarqawi, Sufisme dan Akal, Bandung: Pustaka Hidayah, 2003

Muhammad Izzuddin Taufiq, Panduan Lengkap dan Praktis Psikologi Islam, Jakarta, Gema Insani Press, 2006.

Muhammad Ustman Najjati, Ad-Dirasat al-Nafsaniyah 'inda al-Ulama al-Muslimin, Kairo, Darul Asy-Syuruq, 1993. 